University of Nebraska - Lincoln

DigitalCommons@University of Nebraska - Lincoln

USDA Wildlife Services - Staff Publications

U.S. Department of Agriculture: Animal and

Plant Health Inspection Service

2021

Measuring adrenal and reproductive hormones in hair from

Southern Beaufort Sea polar bears (Ursus maritimus)

Marilize Van der Walt

Lorin A. Neuman-Lee

Patricia A. Terletzky

Todd C. Atwood

Eric M. Gese

See next page for additional authors

Follow this and additional works at: https://digitalcommons.unl.edu/icwdm_usdanwrc

Part of the Natural Resources and Conservation Commons, Natural Resources Management and Policy Commons, Other Environmental Sciences Commons, Other Veterinary Medicine Commons, Population Biology Commons, Terrestrial and Aquatic Ecology Commons, Veterinary Infectious Diseases Commons, Veterinary Microbiology and Immunobiology Commons, Veterinary Preventive Medicine, Epidemiology, and Public Health Commons, and the Zoology Commons

This Article is brought to you for free and open access by the U.S. Department of Agriculture: Animal and Plant Health Inspection Service at DigitalCommons@University of Nebraska - Lincoln. It has been accepted for inclusion in USDA Wildlife Services - Staff Publications by an authorized administrator of DigitalCommons@University of Nebraska - Lincoln. 


\section{Authors}

Marilize Van der Walt, Lorin A. Neuman-Lee, Patricia A. Terletzky, Todd C. Atwood, Eric M. Gese, and Susannah S. French 
Research paper

\title{
Measuring adrenal and reproductive hormones in hair from Southern Beaufort Sea polar bears (Ursus maritimus)
}

\author{
Marilize Van der Walt ${ }^{\text {a, },}$, Lorin A. Neuman-Lee ${ }^{\mathrm{a}, 1}$, Patricia A. Terletzky ${ }^{\mathrm{b}}$, Todd C. Atwood ${ }^{\mathrm{c}}$, \\ Eric M. Gese ${ }^{\mathrm{d}}$, Susannah S. French ${ }^{\mathrm{a}}$ \\ a Department of Biology and the Ecology Center, Utah State University, 5305 Old Main Hill, Logan, UT 84322, USA \\ ${ }^{\mathrm{b}}$ Department of Wildland Resources, Utah State University, 5230 Old Main Hill, Logan, UT 84322, USA \\ ${ }^{c}$ U.S. Geological Survey, Alaska Science Center, 4210 University Drive, Anchorage, AK 99508, USA \\ ${ }^{\mathrm{d}}$ U.S. Department of Agriculture, Wildlife Services, National Wildlife Research Center, Department of Wildland Resources, Utah State University, Logan, UT 84322, USA
}

\section{A R T I C L E I N F O}

\section{Keywords:}

Hair

Cortisol

Reproduction

Testosterone

Progesterone

Estradiol

\begin{abstract}
A B S T R A C T
Polar bears (Ursus maritimus) use sea ice to access marine mammal prey. In Alaska's Southern Beaufort Sea, the declining availability of sea ice habitat in summer and fall has reduced opportunities for polar bears to routinely hunt on the ice for seals, their primary prey. This reduced access to prey may result in physiological stress with subsequent potential consequences to reproductive function (physiological changes that accompany reproduction), which can be measured via reproductive hormones. Hormone concentrations in hair can be used as a minimally invasive alternative to serum concentrations, which must come from animal captures. Hair samples also provide a long-term average measurement of hormone concentrations that is not influenced by short-term fluctuations like that of serum. The aim of this study was (1) to determine if a radioimmunoassay could be used to measure adrenal and reproductive hormones in polar bear hair, and (2) to determine what the relationship is between these hormones and other reproductive, condition, and demographic parameters of polar bears. We successfully validated this method for cortisol, progesterone, estradiol, and testosterone through the analysis of hair and serum of 141 free-ranging polar bears. We found that while hair cannot be used to estimate serum hormone concentrations during the breeding season, hormone concentrations in hair can be used to measure reproductive function in polar bears. Further, our findings support trends in previous studies measuring hormone concentrations in serum. We found that adrenal and some reproductive hormones were positively correlated in hair samples of females. Associations between hormone concentrations in hair and serum did not vary relative to reproductive status of adult females. Serum testosterone increased throughout the breeding season for adult males and was significantly associated with body mass index (BMI). Our research supports the use of hair as a measure of reproductive function in polar bears and allows us to monitor the future effects of climate change on polar bear physiology.
\end{abstract}

\section{Introduction}

\subsection{Threats to polar bear fitness}

Global climate change has affected the availability of Arctic sea ice, causing earlier summer break-up, later freeze-up, and decreased area, with some of the most pronounced changes occurring in the Southern Beaufort Sea (Serreze and Barry, 2011; Stern and Laidre, 2016; Stroeve et al., 2014). This is concerning for the fitness, or lifetime reproductive output and success, of polar bears (Ursus maritimus) because they are specialist carnivores, primarily hunting and consuming ringed (Pusa hispida) and bearded seals (Erignathus barbatus). These seals are most abundant in the shallow, biologically productive water of the continental shelf (Bengtson et al., 2005; Harwood et al., 2012), which is the preferred habitat of polar bears in this region (Durner et al., 2009). Changing sea ice phenology has increased the number of days when sea

\footnotetext{
* Corresponding author.

E-mail addresses: mvanderwaltdvm@gmail.com (M. Van der Walt), lneumanlee@astate.edu (L.A. Neuman-Lee), pat.terletzky@usu.edu (P.A. Terletzky), tatwood@usgs.gov (T.C. Atwood), eric.gese@usu.edu (E.M. Gese).

${ }^{1}$ Present address: Department of Biological Sciences, Arkansas State University, PO Box 599, Jonesboro, Arkansas 72467, USA
} 
ice is absent from the continental shelf, and thus reduced the amount of sea ice available for hunting in summer and fall (Durner et al., 2019).

Decreasing availability of sea ice habitat has been associated with declines in body condition, survival, breeding rates, and abundance of polar bears (Bromaghin et al., 2015; Obbard et al., 2016; Regehr et al., 2010; Rode et al., 2010). Increases in the length of the open-water season, where ice is mostly absent from the continental shelf, reduces access to prey and causes polar bears to become increasingly reliant on stored body fat to meet metabolic demands (Pagano et al., 2018). Adequate energy supplies are especially important to denning pregnant female polar bears who fast throughout the winter while being additionally subjected to the highly energetically demanding processes of gestation and lactation (Atkinson and Ramsay, 1995; Thiemann et al., 2006). The stress of prolonged fasting and decreased nutritional condition due to reduced availability of ice may be negatively affecting reproductive success (Atkinson and Ramsay, 1995; Molnár et al., 2011; Rode et al., 2010). More work is currently needed to monitor how these changing conditions are impacting the reproduction and health of freeliving polar bears. In the present study, we examined the value of using hair to measure adrenal and reproductive hormone concentrations, and how these hormones relate to key demographic and life history traits in polar bears.

\subsection{Measuring stress via hair}

Stress consists of two parts: a stressor (a stimulus) and a stress response (the physiological reaction to the stressor). Stressors in polar bears can include endocrine disrupting contaminants, energetic stress, environmental perturbations, and as in most animals, reproduction (Atkinson and Ramsay, 1995; Ciesielski et al., 2017; Haave et al., 2003)

In most mammals, stress can be measured using cortisol, an adrenal glucocorticoid hormone and downstream product of activation of the hypothalamic-pituitaryadrenal (HPA) axis (Wingfield et al., 1998) that changes in response to stress. Chronic stress, characterized by persistently high concentrations of cortisol over weeks to months, has been negatively associated with reproduction in mammals (Tilbrook et al., 2000; Wingfield and Sapolsky, 2003), reptiles, and birds (Wingfield and Sapolsky, 2003), immunity in ground squirrels (Brooks and Mateo, 2013), garter snakes (Neuman-Lee et al., 2015) and many other species (Dhabhar, 2009), and growth in birds, reptiles, and mammals (Wingfield et al., 1998). Similarly to the HPA axis, a hypothalamic-pituitary-gonadal (HPG) axis exists, which regulates reproductive hormone secretion and also interacts with glucocorticoid hormones (Wingfield and Sapolsky, 2003). Hormone concentrations are therefore indicative of the physiologic processes underlying changes brought about by stress, which can help elucidate relationships between stressors and behavior, morphometrics, and other variables.

Measuring adrenal and reproductive hormones has traditionally required collection of a blood sample, but hair has recently been shown to be a viable alternative for some animals (reviewed in Greff et al., 2019 and in Heimbürge et al., 2019), including several species of bear, such as grizzly bears (Cattet et al., 2017; Macbeth et al., 2010; 2012) and polar bears (Bechshøft et al., 2013). Utilization of hair can allow for a less invasive and more cost effective method of collection as polar bear hair can be obtained passively from barbed-wire hair traps (Herreman and Peacock, 2013; Lillie et al., 2019) or opportunistic sampling of carcasses, thereby avoiding the need to physically capture animals.

Throughout the year, hair cycles through several phases (Geyfman et al., 2015). During the hair growth period, the hair follicle is in the phase anagen. The hair proceeds through the phases catagen, a short transition phase, and telogen, a phase thought to be a period of rest or quiescence. The hair is then shed during exogen, corresponding with the annual molt in polar bears, and the cycle is restarted. Hormones are believed to be deposited into hair and feathers through passive diffusion from the vasculature during hair growth as has been described in partridges (Bortolotti et al., 2008), rhesus macaques (Davenport et al.,
2006), and in humans (Russell et al., 2012; Stenn and Paus, 2001). Hair growth in polar bears is believed (i.e., not experimentally confirmed) to occur from mid-May through late October (Amstrup et al., 2003), although the timing of molt is variable (Amstrup et al., 2003; Bechshøft et al., 2013; Derocher and Lynch, 2012; Macbeth et al., 2012; Mislan et al., 2016). Therefore, glucocorticoid and reproductive hormone concentrations in hair should be an average measure of the activity of the central HPA and HPG axes during the previous summer and early fall. In contrast, hormone concentrations in serum would be representative of the adrenal activity and reproductive status at the time of capture. Measuring hormone concentrations in hair gives us the opportunity to potentially eliminate confounding effects of capture stress on cortisol measurements (Cook, 2012; Macbeth et al., 2010; Sheriff et al., 2011).

When measuring hormone concentrations in hair, there are various factors to be considered. For example, in grizzly bears (Ursus arctos), hair steroids have been shown to vary in response to hair type (plucked vs shaved, Cattet et al., 2017; guard hairs vs undercoat, Macbeth et al., 2010), location of collection on the body (Macbeth et al., 2010), method of collection (e.g. live-captured vs barbed-wire hair traps; Cattet et al., 2014; Macbeth et al., 2010), and methods of washing during processing (Kroshko et al., 2017; Macbeth et al., 2010). Hair steroids have also been shown to vary across body sites in humans (Sharpley et al., 2010). No differences in concentration along the length of the hair has been found in grizzly bears (Macbeth et al., 2010) or rhesus macaques (Davenport et al., 2006).

\subsection{Reproductive physiology}

The annual reproductive timeline of polar bears has been described (Amstrup, 2003; Ramsay and Stirling, 1988). Polar bears breed from April through June (Smith and Aars, 2015; Stirling et al., 2016). They then undergo a period of embryonic diapause, where the fertilized egg remains in a state of dormancy and gestation is arrested. The fertilized egg finally implants in the uterus in the fall. At this point, pregnant females enter their dens while solitary females and females with cubs do not den. The total gestation is about 195-265 days, with most births occurring in January (Amstrup and Gardner, 1994). Females with cubs typically exit dens by late March (Rode et al., 2018).

There are limited data on the annual reproductive physiology of polar bears, in part due to constraints in data collection, such as the inability to sample hibernating bears and the invasiveness of sampling. Evidence from using reproductive hormones in serum suggests that in male polar bears, testosterone peaks in the spring before decreasing and reaching low concentrations in the late summer and fall (Ciesielski et al., 2017; Oskam et al., 2003; Palmer et al., 1988). Fecal testosterone concentrations in captive male polar bears have shown a similar trend (Curry et al., 2012).

In females, progesterone (the hormone responsible for maintenance of pregnancy) concentration in serum and urine rises directly after conception and increases throughout the year, peaking in October when implantation of the fertilized oocyte occurs (Derocher et al., 1992; Palmer et al., 1988; Ramsay and Stirling, 1988). While progesterone concentrations usually remain low in non-pregnant polar bears and have therefore been used as a proxy for pregnancy determination, polar bears may undergo pseudopregnancy where the physiologic changes following ovulation occur without successful fertilization (Derocher et al., 1992). It is therefore difficult to determine whether elevated serum progesterone concentration without a record of cubs the following spring is due to failure of implantation, pregnancy loss, cub mortality, or pseudopregnancy. Attempts to determine pseudopregnancy using fecal and urinary hormones in captive female polar bears have so far been unreliable (Bryant and Roth, 2018; Knott et al., 2017; Stoops et al., 2012).

Serum concentrations of estradiol peak in August (Palmer et al., 1988), with no difference in concentrations with pregnancy status 
Table 1

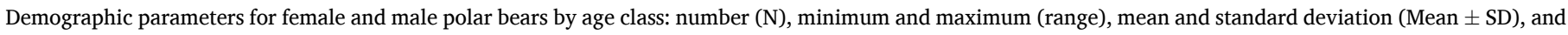
number of cubs present.

\begin{tabular}{|c|c|c|c|c|c|c|c|c|}
\hline & \multicolumn{4}{|l|}{ Females } & \multicolumn{4}{|l|}{ Males } \\
\hline & All & Adult & Subadults & Cubs & All & Adult & Subadults & Cubs \\
\hline $\mathrm{N}$ & 80 & 53 & 21 & 6 & 61 & 37 & 10 & 4 \\
\hline N Ages (years) & 25 & 13 & 9 & 3 & 22 & 10 & 3 & 0 \\
\hline Range & $1-18$ & $5-18$ & $2-4$ & $1-2$ & $1-21$ & $5-21$ & $3-3$ & - \\
\hline Mean \pm SD & $6.57 \pm 4.98$ & $10.00 \pm 4.69$ & $3.22 \pm 0.83$ & $1.67 \pm 0.58$ & $7.23 \pm 6.18$ & $11.30 \pm 5.93$ & 0 & - \\
\hline N BMI (\%) & 71 & 49 & 18 & 4 & 47 & 33 & 10 & 3 \\
\hline Range & $28.13-62.77$ & $34.15-53.08$ & $28.13-62.77$ & $30.65-34.85$ & $24.52-75.31$ & $34.16-75.31$ & $26.71-48.34$ & $24.52-32.32$ \\
\hline Mean \pm SD & $41.01 \pm 5.86$ & $42.21 \pm 4.69$ & $39.56 \pm 7.53$ & $32.87 \pm 1.79$ & $50.55 \pm 13.15$ & $55.89 \pm 11.18$ & $40.69 \pm 6.53$ & $27.70 \pm 4.09$ \\
\hline N Date & 78 & 53 & 20 & 5 & 56 & 37 & 12 & 3 \\
\hline Date Range & $1-45$ & $1-45$ & $10-45$ & $20-37$ & $2-45$ & $2-44$ & $2-35$ & $6-45$ \\
\hline Mean \pm SD & $22.61 \pm 9.32$ & $21.15 \pm 9.12$ & $26.05 \pm 9.70$ & $24.40 \pm 7.16$ & $18.20 \pm 11.29$ & $18.70 \pm 10.72$ & $19.17 \pm 11.80$ & $19.00 \pm 22.52$ \\
\hline Cubs present/absent & $29 / 43$ & $28 / 25$ & $1 / 18$ & - & 0 & 0 & 0 & - \\
\hline
\end{tabular}

(Haave et al., 2003; Palmer et al., 1988). Fecal estradiol concentrations did not show a pattern corresponding to physiologic events (Stoops et al., 2012). Estradiol is produced by follicles in the ovaries and is typically involved with growth and maturation of reproductive tissues in preparation for implantation. The role of estradiol in pregnancy in ursids is not clearly understood, though it may represent follicular activity in polar bears (Palmer et al., 1988).

\subsection{The scope of this study}

In this study we used paired samples from hair and serum to measure concentrations of cortisol, testosterone, estradiol, and progesterone of adult and subadult polar bears from Alaska's Southern Beaufort Sea subpopulation sampled annually between March and May for population dynamics studies (Atwood et al., 2016). Our aim was to determine the usefulness of hair in measuring reproductive hormone concentrations and to gain a better understanding of the physiological processes underlying relationships between bear morphometric data, hair cortisol, and reproduction. The present study expanded on a previous effort that measured hair cortisol and immune parameters (Neuman- Lee et al., 2017) by analyzing the relationship between hair cortisol and reproductive hormones (in both the hair and blood) and pregnancy success.

We sampled hair and serum during a period when hair was not growing (March-May), thus serum hormone concentrations should reflect physiology at time of capture, whereas hair hormones should reflect condition during the previous summer and early fall (MayOctober) when bears were molting and re-growing hair. We predicted that serum testosterone concentrations in males would be high and testosterone concentrations in males in hair would be low at the time of capture. We also expected progesterone concentrations in hair would be high in females with cubs as they would have been pregnant the previous summer and fall, and low in females without cubs, while progesterone concentrations from serum would be low in all females at the time of capture. Finally, we predicted that estradiol concentrations in hair would be high in all females following a peak the previous summer, while estradiol concentrations in serum would be low.

\section{Methods/materials}

\subsection{Sample collection}

Male $(n=61)$ and female $(n=80)$ polar bears were captured by helicopter between late March and early May of 2013, 2014, and 2015 on sea ice of the Southern Beaufort Sea within $90 \mathrm{~km}$ of the coastline of Alaska. The bears were chemically immobilized for approximately 45-60 min for data collection. Blood was collected from the femoral or jugular vein around the midway point of processing (20-30 min). Hair was sampled by using forceps to pull hairs from multiple locations from the rump and back. Enough hair was pulled to fill at least half of a $7 \mathrm{oz}$ whirl pak bag. We previously performed validations testing for differences in cortisol concentrations in guard hairs versus undercoat, as well as sectioning the hair to look at the potential for temporal differences in cortisol deposition. We found no significant differences in cortisol among hair types or hair sections within a given bear (French, unpublished data). Thus, all samples represent a combination of hair types that were collected and processed in a consistent manner. The date, age, sex, body mass, presence of cubs-of-the-year (COY) or yearlings, and number and ages of cubs were recorded.

Age of dependent young accompanied by an adult female was determined based on size (COY are significantly smaller than yearlings). Age of subadults ( $2-4$ yr) and adults ( $\geq 5$ yr) was determined by analysis of the cementum annuli of a vestigial premolar that was removed at their first capture. Body mass index (BMI) was calculated as described in the following equation commonly used in bear studies: BMI = body mass $(\mathrm{kg}) /$ standard body length (m) ${ }^{2}$ (Cattet et al., 2002; Obbard et al., 2016; Rode et al., 2010). BMI considers mass in the context of body length so it indexes body condition relative to structural size/growth differences. Blood samples were centrifuged within $6 \mathrm{~h}$ of sampling, aliquotted into $2 \mathrm{ml}$ cryovials, and frozen in a standard freezer $\left(0^{\circ} \mathrm{F}\right)$ until it was transported to Anchorage. Once in Anchorage, samples were stored in a $-80^{\circ} \mathrm{F}$ freezer. Hair samples were stored in plastic bags at room temperature.

Metrics varied among sex and age classes of captured polar bears (Table 1). Of the 28 adult females with cubs, 12 had two cubs (5 with COY, 4 with yearlings, 3 with two-year olds) and 13 had one cub (7 with COY, 4 with yearlings, 2 with two-year olds). One adult had COY (unknown number) and two adults had yearlings (unknown number). There was one subadult with one COY.

\subsection{Hormone analyses}

Hormone concentrations in hair were measured using a protocol described by Neuman-Lee et al. (2015) and others (Davenport et al., 2006; Macbeth et al., 2012), and hormone concentrations in serum were measured using a protocol modified from Moore (1986). Hair samples were cleaned by washing with HPLC-grade methanol three times, allowed to dry, then weighed; sample mass averaged $133.3 \mathrm{mg} \pm 58.4$ $\mathrm{mg}$ (SD). In cases where the sample mass was below $150 \mathrm{mg}$, the entire sample was used. The smallest hair sample measured that had detectable levels was $34.3 \mathrm{mg}$. We then ground the hair using a Restch ball mill (Restch, Verder Scientific, Germany) with $7 \mathrm{~mm}$ steel grinding balls. Samples were ground for $10 \mathrm{~min}$ at $30 \mathrm{~Hz}$. Balls and vials were cleaned thoroughly with ethanol, and dried before grinding the next sample. The ground hair was weighed and transferred to an Eppendorf tube. We added $3 \mathrm{ml}$ of methanol to the sample, vortexed it for $1 \mathrm{~min}$, then placed samples on a slow vortexer for $24 \mathrm{~h}$. After vortexing, samples were then spun for $10 \mathrm{~min}$ at $2000 \mathrm{rpm}$, and $1.5 \mathrm{ml}$ of the supernatant was removed and placed in a clean glass tube. Samples were dried under a stream of 
Table 2

Assay parameters for hair and serum estradiol (E2), progesterone (P), testosterone (T), and cortisol (C) hormone radioimmunoassay or enzyme immunoassay (EI) in polar bears (Ursus maritimus). Validation assay parameters reported here are the recovery, linearity, and intra-assay coefficient of variation (COV). Validation intra-assay COV are not reported as they share the same values as inter-assay COV. Sample assay parameters reported here are the average intraassay COV and the inter-assay COV. ${ }^{* *}$ Cortisol radioimmunoassays were validated but samples were not measured because hair cortisol has been previously analyzed via EI in Neuman-Lee et al. (2017), and because serum cortisol concentration would be influenced by capture stress. Sample specifics can be found in Neuman-Lee et al. (2017).

\begin{tabular}{|c|c|c|c|c|c|}
\hline & \multicolumn{3}{|c|}{ Validation Assays } & \multicolumn{2}{|c|}{ Sample Assays } \\
\hline & Recovery & $\begin{array}{l}\text { Linearity } \\
\left(R^{2}\right)\end{array}$ & $\begin{array}{l}\text { Inter- } \\
\text { assay COV }\end{array}$ & $\begin{array}{l}\text { Intra- } \\
\text { assay COV }\end{array}$ & $\begin{array}{l}\text { Inter- } \\
\text { assay COV }\end{array}$ \\
\hline $\begin{array}{l}\text { Female Hair } \\
\quad \text { E2 }\end{array}$ & $99.0 \%$ & $81.5 \%$ & $1.2 \%$ & $3.2 \%$ & $4.0 \%$ \\
\hline $\begin{array}{l}\text { Female } \\
\text { Serum E2 }\end{array}$ & $99.9 \%$ & $98.5 \%$ & $18.4 \%$ & $18.6 \%$ & $26.1 \%$ \\
\hline $\begin{array}{l}\text { Female Hair } \\
\quad \text { P }\end{array}$ & $85.6 \%$ & $98.7 \%$ & $5.7 \%$ & $6.4 \%$ & $5.8 \%$ \\
\hline $\begin{array}{l}\text { Female } \\
\text { Serum P }\end{array}$ & $87.4 \%$ & $98.5 \%$ & $6.7 \%$ & $15.8 \%$ & $18.9 \%$ \\
\hline Male Hair T & $100.1 \%$ & $96.5 \%$ & $5.4 \%$ & $1.6 \%$ & $1.6 \%$ \\
\hline $\begin{array}{l}\text { Male Serum } \\
\quad \mathrm{T}\end{array}$ & $71.6 \%$ & $99.6 \%$ & $17.9 \%$ & $9.1 \%$ & $9.1 \%$ \\
\hline $\begin{array}{l}\text { Female Hair } \\
\quad \text { C }\end{array}$ & $94.8 \%$ & $92.5 \%$ & $3.2 \%$ & $* *$ & $* *$ \\
\hline $\begin{array}{l}\text { Female } \\
\text { Serum C }\end{array}$ & $65.7 \%$ & $95.8 \%$ & $1.2 \%$ & $* *$ & $* *$ \\
\hline Male Hair C & $94.8 \%$ & $93.3 \%$ & $3.2 \%$ & $* *$ & $* *$ \\
\hline $\begin{array}{l}\text { Male Serum } \\
\quad \text { C }\end{array}$ & $101.9 \%$ & $99.6 \%$ & $1.2 \%$ & $* *$ & $* *$ \\
\hline Hair C (EI) & $92.8 \%$ & $99.6 \%$ & - & $2.4 \%$ & $4.2 \%$ \\
\hline
\end{tabular}

nitrogen and then resuspended in an assay dilutant (supplied by Salimetrics, State College, PA). Serum hormones were extracted with a $30 \%$ ethyl acetate/isooctane phase and flash-frozen to decant the nonpolar solvent from the aqueous phase. The ethyl acetate phase was then dried and resuspended in a phosphate buffer solution.

Cortisol concentrations in hair were validated for radioimmunoassay (Table 2), however, the samples were previously measured via enzyme immunoassay (Salimetrics, State College, PA) following the manufacturer's instructions (Neuman- Lee et al., 2017), and those data were used for statistical analysis in the present study. Because of the acute stress response and subsequent release of cortisol following capture, serum cortisol was not measured. Reproductive hormones were both validated and measured via radioimmunoassay. Validation used pooled samples for hair and serum (small amounts of several samples were combined into one sample for the validation), and tested for parallelism, interference, and matrix effect (Table 2). Samples were assayed in duplicate, and separate assays were used to measure each reproductive hormone. Antibodies used, their production company, and the cross-reactivities for each are: progesterone (Fitzgerald; Pregnenolone $<50.0 \%$, Dehydroepiandrosterone $<0.03 \%$, Hydrocortisone $<0.03 \%$, Prednisone $<$ $0.3 \%$, 4-Androstenedione $<0.3 \%$, Corticosterone: $<0.4 \%$, Spiranolactone $<0.3 \%$, Cortisone $<0.15 \%$, 11-Deoxycortisol $<1.0 \%$ ), testosterone (Fitzgerald; 5a-Dihydrotestosterone 63\%, s-1-testosterone 46\%, 5a-Androstan-3a,17b-diol 4.1\%, s -5-Androsten-3b, 17b-diol $14 \%$, 5a-Androstan-3,17-dione $<4.0 \%$, epi-testosterone $<0.7 \%$, Aldosterone $<4.0 \%$, Hydrocortisone $<0.02 \%$, Progesterone $<0.2 \%$ ) estradiol (BioRad; 17-beta Oestradiol 100\%, Oestrone 14\%, Oestriol 5\%; Aldosterone, Cortisol, Corticosterone, DHEA, Deoxycorticosterone, Pregnenolone, Progesterone, 170H-P and Testosterone all $<0.01 \%$ ), and cortisol (Fitzgerald; Cortisol 100\%, Prednisolone 36.0\%, 11-Desoxycortisol 5.7\%, Corticosterone 3.3\%). The intra- and inter-assay coefficients of variation were calculated for each reproductive hormone for both the validation and sample assays (Table 2).

Briefly, we pipetted the samples, controls, and zeros (blanks to control for nonspecific binding) onto the supplied plate and added the enzyme conjugate (diluted to 1:1600). After mixing for five minutes and incubating at room temperature for one hour, the plate was washed four times with the supplied wash buffer using a plate washer. TMB Substrate solution (Salimetrics, State College, PA) was added, mixed for five minutes, and then incubated for another $25 \mathrm{~min}$ at room temperature. Finally, the stop solution was added, the plate was mixed, and the plate was read at $450 \mathrm{~nm}$, with a secondary filter correction at $490 \mathrm{~nm}$, using a BioRad xMark Microplate reader. Standard curves, controls, and controls for non-specific binding were run on each plate. Cross-reactivity to other steroid hormones is $<0.25 \%$, with the highest cross-reactivity to corticosterone at $0.21 \%$. Average intra-assay and inter-assay variation varied among samples and assays (Table 2). Coefficients of variation were calculated using a standard value included in each assay (Table 2).

\subsection{Data analyses}

To improve accuracy, final hormone concentrations in hair were adjusted for volume used in assay (400ul total volume after extraction and resuspension divided by $25 \mathrm{ul}$ used in the assay) and amount recovered from extractions ( $3 \mathrm{ml}$ total extractant added divided by 1.5 $\mathrm{ml}$ extractant plus sample hormone recovered). To meet assumptions of normality, values for ages and both hair and serum concentrations for progesterone, estradiol, and testosterone concentrations were log transformed. Relationships between reproductive hormones and the other metrics were evaluated separately by sex, and females were evaluated by age class. Males were not evaluated separately by age class because of low sample sizes. Sexes were analyzed separately for all analyses. Hair and serum samples were compared using a Pearson correlation analysis $(\alpha=0.05)$. Cortisol and female progesterone and estradiol were compared with presence of cubs and cub status (COY or not) using a Student's $t$-test, and cub number (0-2) and cub age in years using ANOVAs. Pearson's correlation analyses were used to compare cortisol and reproductive hormones with condition (BMI and body mass), age, and date. Growth curves for SB bears indicate that females reach asymptotic growth around 5 years of age and males reach it at around 10 years (Rode et al., 2010). Because BMI and mass were highly correlated $\left(\mathrm{R}^{2}=0.889, p<0.001, \mathrm{~N}=74\right)$, BMI has been reported in place of mass. For analysis using date, the earliest date of capture, March 24th, was assigned the number 1 and every subsequent day through the last date of capture, May 7th was assigned the consecutive number through 45 .

The samples in the present study expanded on a previous study measuring hair cortisol and immune parameters (Neuman- Lee et al., 2017). No additional hair samples were included in this study, but additional parameters investigated here include reproductive hormones (progesterone, estradiol, and testosterone) and cub demographics (presence of cubs, number of cubs, COY status, or age of cubs). Immune parameters, and the relationships between reproduction, cortisol and mass, condition, and age were previously investigated in Neuman-Lee et al (2017). It should also be noted that there are a few deviations in numbers from Neuman-Lee et al. (2017) due to adjusting cub presence/ absence data. If a cub number was assigned to the female, but there was no value for cub presence/absence, then the presence/absence was assigned post hoc, which increased our sample size in that category slightly from the previous study.

For some individuals we were not able to obtain measurements for all parameters. For example, age could not be determined for bears that started to recover from sedation before a tooth could be removed. As a result, the sample size varies for each correlation. For Student's t tests, reported p-values are two-tailed. Significance was determined using an alpha level of 0.05 , and we also considered the $\mathrm{R}^{2}$ for how much variation was actually explained along with consideration of its biological relevance. Data were analyzed using JMP 13.0.0 software (SAS Institute Inc., Cary, NC). 


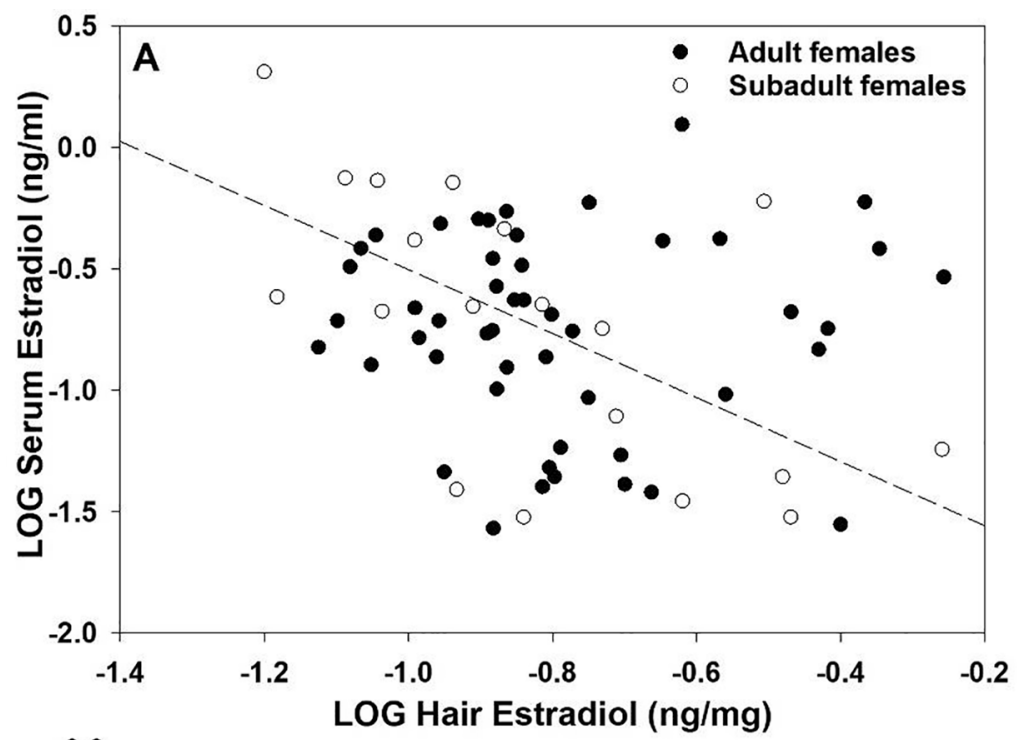

Fig. 1. Relationships between polar bear hair and serum reproductive hormones. Concentrations from hair and serum were related for estradiol concentrations in subadult females $\left(\mathrm{R}^{2}=0.370, \mathrm{p}=0.006\right.$, $\mathrm{N}=19$; graph $\mathrm{A}$; trend line shown), but not for estradiol concentrations in adult females $\left(\mathrm{R}^{2}<0.001, \mathrm{p}=0.907, \mathrm{~N}=49\right.$; graph $\left.\mathrm{A}\right)$, progesterone concentrations in subadults $\left(R^{2}=0.071, p=0.271, N\right.$ = 19; graph B), progesterone in adult females $\left(\mathrm{R}^{2}<0.001, \mathrm{p}=\right.$ 0.9334, $N=48$; graph B), and testosterone in males $\left(R^{2}=0.041, p=\right.$ $0.215, \mathrm{~N}=39$; graph $\mathrm{C}$ ).
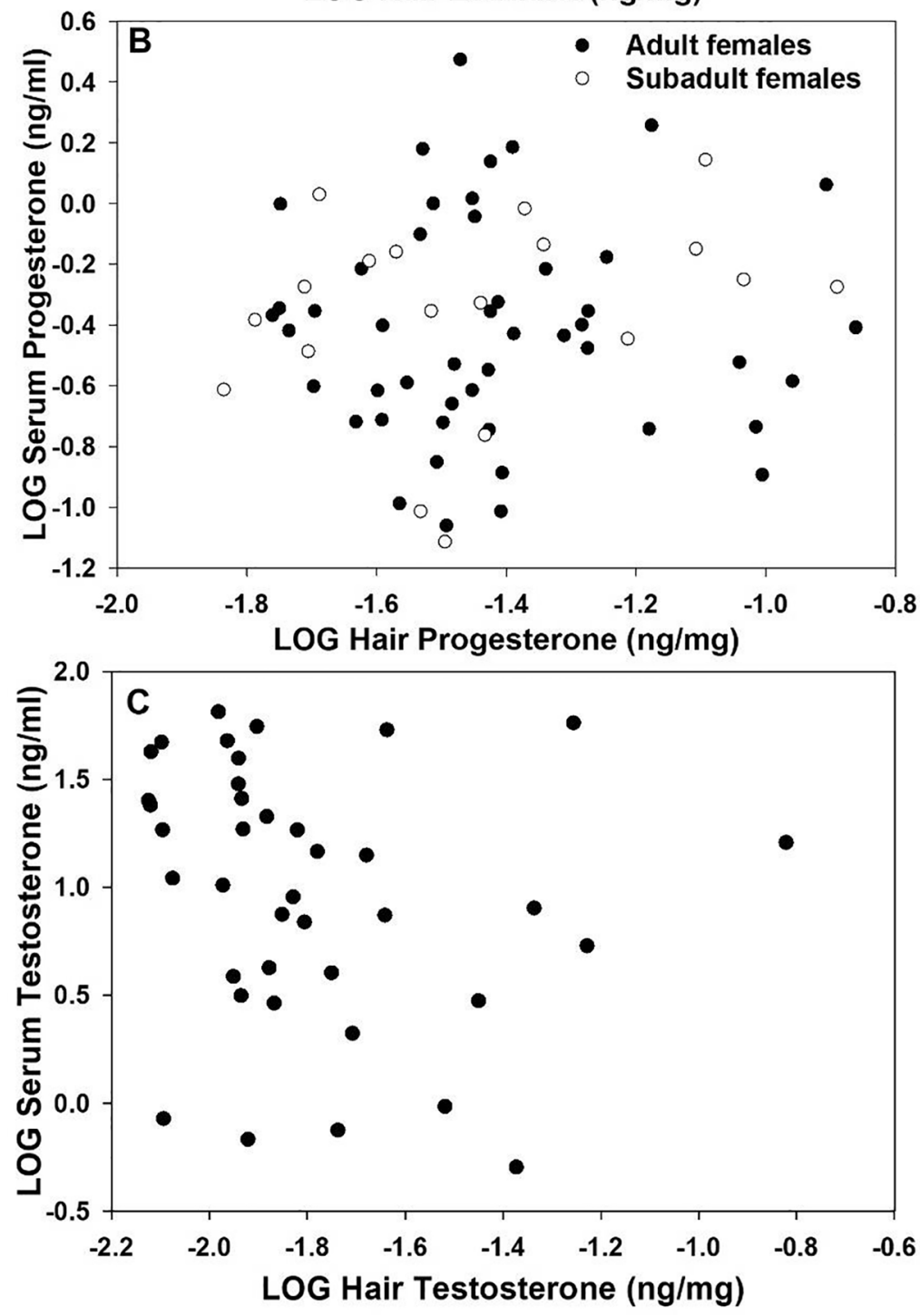


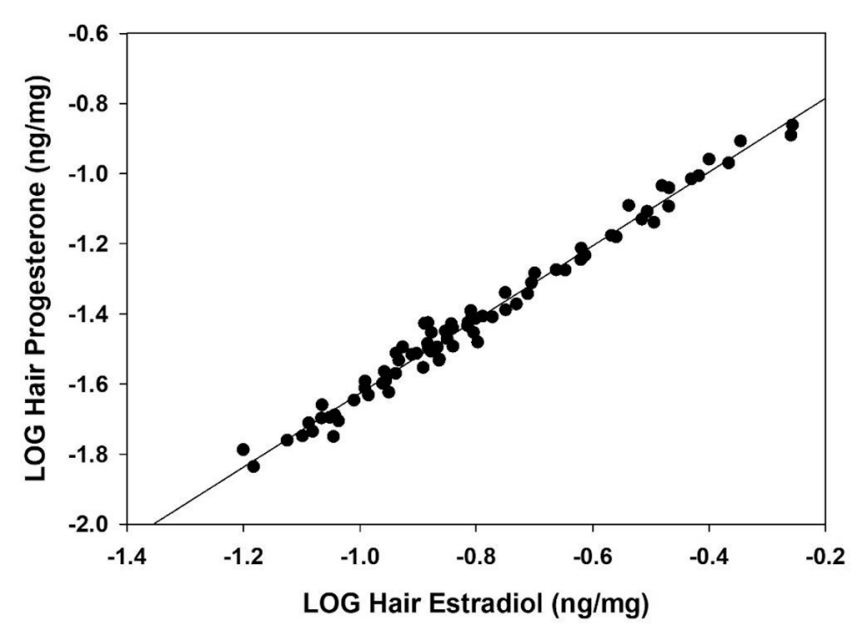

Fig. 2. Relationship between female polar bear hair estradiol and progesterone. Estradiol and progesterone hair concentrations were positively related $\left(\mathrm{R}^{2}=\right.$ 0.983, $\mathrm{p}<0.001, \mathrm{~N}=77$ ).

\section{Results}

\subsection{Cortisol and reproductive function}

Progesterone and estradiol concentrations in polar bear hair were correlated in adult females $\left(\mathrm{R}^{2}=0.981, p<0.001, \mathrm{~N}=50\right)$ and subadult females $\left(\mathrm{R}^{2}=0.990, p<0.001, \mathrm{~N}=21\right.$, Fig. 2). When comparing cortisol concentrations and reproductive hormones in females, we found there were significant positive correlations between cortisol and estradiol concentrations $\left(\mathrm{R}^{2}=0.229, p=0.001, \mathrm{~N}=49\right.$, Fig. $\left.3 \mathrm{~A}\right)$, and cortisol and progesterone concentrations $\left(\mathrm{R}^{2}=0.201, p=0.001, \mathrm{~N}=49\right.$, Fig. 3B) in hair from adults, but not subadults (estradiol: $\mathrm{R}^{2}=0.132, p=$ $0.105, \mathrm{~N}=21$, Fig. 3A; progesterone: $\mathrm{R}^{2}=0.097, p=0.170, \mathrm{~N}=21$, Fig. 3B). In male polar bears, there was no relationship between hair cortisol and hair testosterone concentrations $\left(\mathrm{R}^{2}=0.050, p=0.117, \mathrm{~N}\right.$ $=50$, Fig. $3 \mathrm{C}$ ) or hair cortisol and serum testosterone concentrations $\left(\mathrm{R}^{2}\right.$ $=0.042, p=0.207, \mathrm{~N}=40$ ). Progesterone and estradiol concentrations in both hair and serum were not related to the presence of cubs, number of cubs, COY status, or age of cubs ( $p>0.05)$.

\subsubsection{Reproductive hormones and demographic parameters}

There was a significant positive relationship between serum testosterone concentrations and age $\left(\mathrm{R}^{2}=0.520, p=0.008, \mathrm{~N}=12\right.$, Fig. 4), and a significant negative relationship between hair testosterone concentrations and age $\left(\mathrm{R}^{2}=0.382, p=0.004, \mathrm{~N}=20\right)$. Hair cortisol $\left(\mathrm{R}^{2}=\right.$ $0.087, p<0.001, \mathrm{~N}=126)$ and serum testosterone concentrations $\left(\mathrm{R}^{2}=\right.$ $0.089, p=0.049, \mathrm{~N}=44$ ) increased throughout the breeding season. Age and date were not significantly associated with any other parameters (Table 3). BMI was not significantly associated with any reproductive hormones besides serum testosterone $\left(\mathrm{R}^{2}=0.558, p<0.001, \mathrm{~N}=\right.$ 34, Table 3).

\subsection{Serum and hair}

Among all the samples examined for captured polar bears, many parameters were correlated (Table 3 ). Though hair and serum concentrations reflect different time periods and therefore we would not expect to see a relationship, hair and serum estradiol concentrations were correlated in subadult females $\left(\mathrm{R}^{2}=0.370, p=0.006, \mathrm{~N}=19\right.$, Fig. $\left.1 \mathrm{~A}\right)$, but not in adult females $\left(\mathrm{R}^{2}<0.001, p=0.907, \mathrm{~N}=49\right.$, Fig. $\left.1 \mathrm{~A}\right)$. There were no relationships between hair and serum for progesterone concentrations in subadults $\left(\mathrm{R}^{2}=0.071, p=0.271, \mathrm{~N}=19\right.$, Fig. $\left.1 \mathrm{~B}\right)$ and adult females $\left(\mathrm{R}^{2}<0.001, p=0.9334, \mathrm{~N}=48\right.$, Fig. $\left.1 \mathrm{~B}\right)$, and testosterone in males $\left(\mathrm{R}^{2}=0.041, p=0.215, \mathrm{~N}=39\right.$, Fig. 1C).

\section{Discussion}

\subsection{Cortisol and reproductive function}

This study adds insight into the measurement of four steroid hormones derived from polar bear serum and hair. In adult females, we found that cortisol and reproductive hormones in hair were correlated: there was a positive relationship between concentrations of cortisol and estradiol, and cortisol and progesterone. These relationships have been previously described for the hair of grizzly bears (Cattet et al., 2017). We may see this relationship because pregnancy and preparation for pregnancy is a highly energetically demanding process. Access to prey is limited during the open-water period, and because bears typically enter dens as ice is reforming over shallower water foraging areas, there is little to no opportunity to productively forage before entering dens. Therefore, bears undergo a period of hyperphagia in the spring where they must gain as much weight possible to have retained sufficient fat reserves (about 20\% body fat; Robbins et al., 2012) in the fall to have a successful pregnancy. The relationship between the length of the openwater season and reproductive success has been modelled in Molnár et al. (2020): they found impaired cub recruitment could occur if fasting lasted longer than 117 days. The impact on reproduction of restricted access to food depends on condition leading up to the open-water period, energy obtained and expended during the open-water period, and open-water period duration (Atkinson and Ramsay, 1995; Rode et al., 2010). Finally, cortisol and reproductive hormones in females may be positively related because both are produced through similar mechanisms and from the same precursor, cholesterol, so there may be a similar mechanism of uptake into hair secondary to cutaneous production of reproductive hormones as cortisol (Slominski et al., 2012).

\subsection{Reproductive hormones and reproductive success}

Similarly to cortisol, production pathways and uptake secondary to cutaneous production of reproductive hormones may explain the close relationship between hair progesterone and estradiol, where concentrations were positively correlated in both adult and subadult females. Alternatively, this relationship could represent concurrent changes in both hormones in response to reproductive changes. There may also be a common seasonal pattern between adults and subadults. The role of estradiol in polar bear reproduction is not well known, but may be related to ovarian follicular activity (Palmer et al., 1988). In many vertebrate models, estradiol traditionally plays a role in maintenance of pregnancy and in parturition of mammals (reviewed in Brenner and West, 1975). It is unlikely that our result was an antibody artifact as the antibody cross reactivity is $<0.01 \%$.

In contrast to the positive relationship found in this study, Cattet et al. (2017) found a negative relationship between progesterone and estradiol concentrations in grizzly bears. This may be because many of the bears used in their study were administered megestrol acetate, a progestational with anti-estrogen activity (Edgren et al., 1967), as a form of birth control for a portion of the year overlapping the breeding season. Additional factors which could explain this difference include species differences or the sampling time-frame used in Cattet et al. (2017), which was year-round instead of just the breeding season. The authors also reported that their measured estradiol values were less accurate than their progesterone and testosterone assay values based on many of the values being at the low end of the dilution curve and there being a high and inconsistent extraction efficiency.

Serum progesterone is higher in pregnant polar bears and is highest in October upon implantation (Derocher et al., 1992; Palmer et al., 1988; Ramsay and Stirling, 1988), i.e. throughout the hair growth period, so we would expect to see higher hair progesterone concentrations in bears with COY the next spring. We did not see a relationship between hair progesterone concentrations and COY status which may be due to difficulty confirming pregnancy status. While we can confirm 

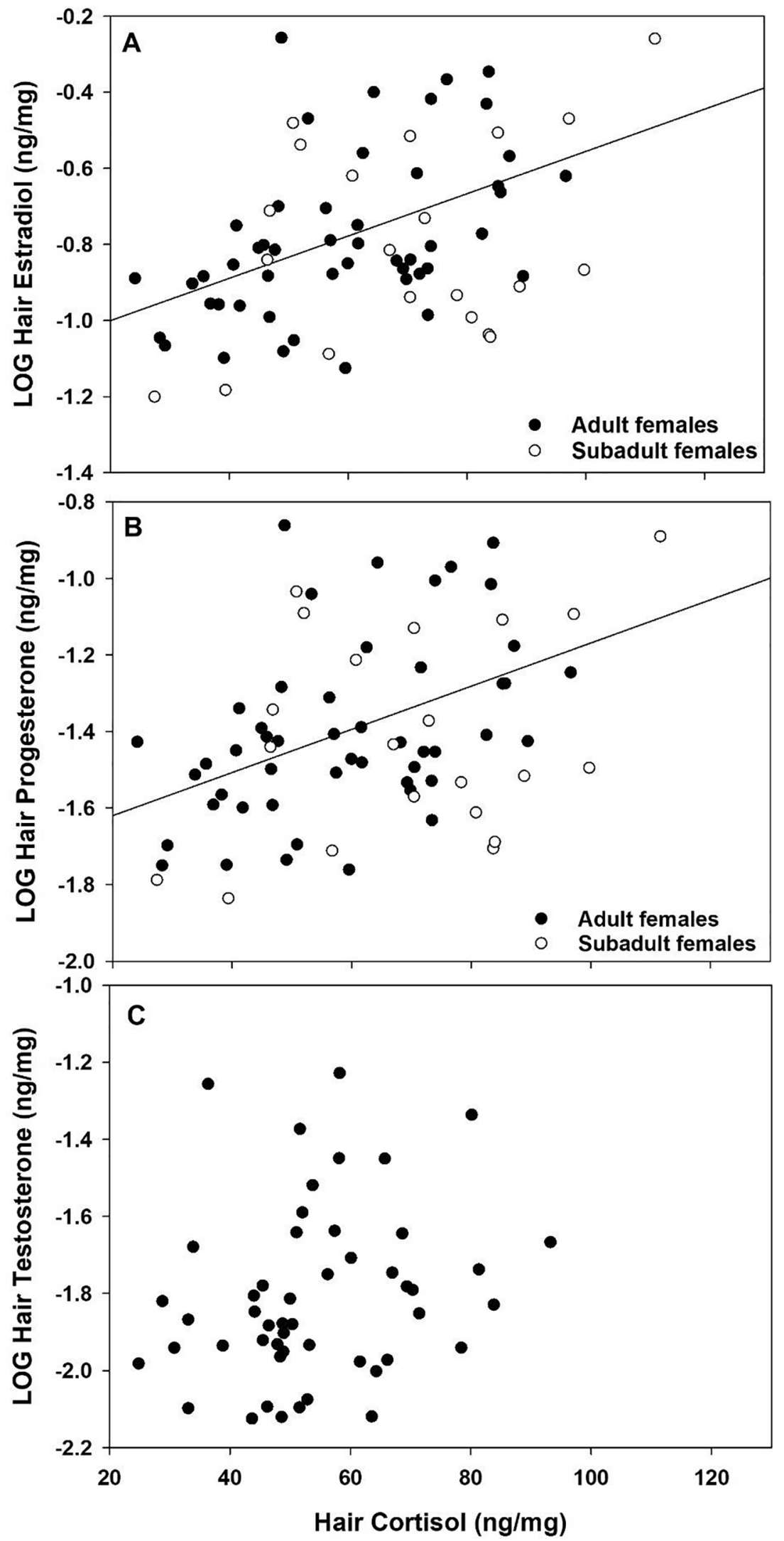

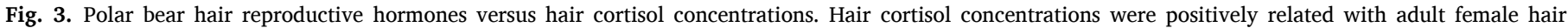

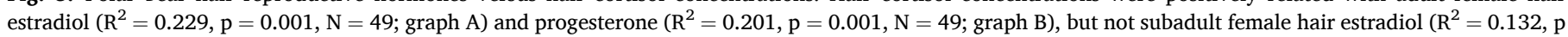
$=0.105, \mathrm{~N}=21$; graph $\mathrm{A})$ and progesterone $\left(\mathrm{R}^{2}=0.097, \mathrm{p}=0.170, \mathrm{~N}=21\right.$; graph $\left.\mathrm{B}\right)$, or testosterone in males $\left(\mathrm{R}^{2}=0.050, \mathrm{p}=0.117, \mathrm{~N}=50 ;\right.$ graph $\mathrm{C}$. 


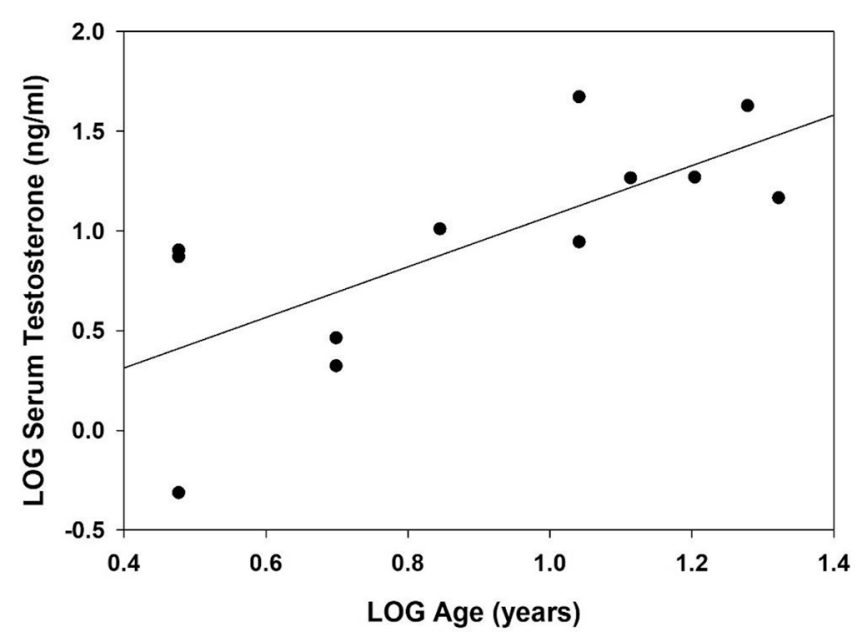

Fig. 4. Relationship between male polar bear serum testosterone and age. Serum testosterone was positively related with age $\left(R^{2}=0.520, p=0.008, N\right.$ $=12$ ).

pregnancy in females with COY, we cannot confirm that single females may have been pregnant the previous year and were just reproductively unsuccessful. These females could have no cubs because of failure of implantation, abortion, cub mortality, or they separated from 2 yr-old cubs prior to capture. Furthermore, more information is needed about the relationships between breeding behaviors, endocrine changes, and pseudopregnancy. All of these extra variables could preclude us from seeing trends in hair progesterone concentrations.

\subsection{Reproductive hormones and demographics relationships}

Our study showed no relationships between reproductive hormones (estradiol and progesterone) in hair or serum of females and BMI, date, and age. This aligns with previous studies where serum estradiol and progesterone concentrations have been found to have no correlation with age (Gustavson et al., 2015; Haave et al., 2003) or serum cortisol (Haave et al., 2003). Serum estradiol concentration has also been shown to have no correlation with capture date (Haave et al., 2003).

In males, serum testosterone concentrations and BMI were positively associated, and this is likely influenced by age, as older males have been shown to have higher testosterone concentrations (Ciesielski et al., 2017; Howell-Skalla et al., 2002; Oskam et al., 2003; Palmer et al., 1988), a finding also supported by this study. The relationship between BMI and hair testosterone concentration was not significant. Testosterone decreases to base-line throughout the nonbreeding season (Ciesielski et al., 2017; Howell-Skalla et al., 2002; Oskam et al., 2003; Palmer et al., 1988), so if there is no difference in testosterone concentrations among different BMI during the non-breeding season, we might not expect to see a relationship between BMI and hair concentrations. If age is used as a proxy for weight, there is no difference among age classes in both serum (Palmer et al., 1988) and fecal (Curry et al., 2012) testosterone concentrations in the non-breeding season. Our study did find a relationship between age and hair testosterone but based on trends in previous studies and the evidence presented here, this might be another indication of a method of hormone uptake alternative to passive diffusion. This may be the case if, for example, hormone uptake from circulation into the hair shaft is influenced by testosterone concentrations in the breeding season. Serum testosterone also increased throughout the breeding season which has also been described previously in polar bears (Palmer et al., 1988). This is in contrast to some studies in polar bears (Howell-Skalla et al., 2002; Oskam et al., 2003) that have found serum testosterone to be higher in March-April than in April-May. This discrepancy could be attributed to the differences in capture period lengths and potential behavioral and physiological differences associated with the geographic regions each study sampled.

\subsection{Hormone deposition in hair}

We found that hair cortisol concentrations increased over the capture period for both males and females at a time of supposed hair quiescence. This may suggest that cortisol is entering the hair outside of the hair growth periods. However, it should be noted that our sample size is relatively small and this relationship only accounted for $8 \%$ of the variance, a fairly weak relationship. Contemporary belief has been that steroid concentrations in hair are a result of uptake into the shaft during the hair growth season only, which has been shown in rhesus macaques

Table 3

Summary of the relationship between estradiol (E2), progesterone (P), testosterone (T), cortisol (C), and other parameters in polar bears (Ursus maritimus) from the Southern Beaufort Sea. Statistically significant tests based on Pearson correlation analyses (alpha $=0.05$ ) are bolded.

\begin{tabular}{|c|c|c|c|c|c|c|c|c|c|c|}
\hline & \multicolumn{4}{|c|}{ Adult Females } & \multicolumn{4}{|c|}{ Subadult Females } & \multicolumn{2}{|l|}{ Males } \\
\hline & Hair E2 & Serum E2 & Hair P & Serum P & Hair E2 & Serum E2 & Hair P & Serum P & Hair $\mathrm{T}$ & Serum $\mathrm{T}$ \\
\hline Serum E2 & $\begin{array}{l}\mathrm{R}^{2}<0.001 \\
\mathrm{p}=0.907 \\
N=49\end{array}$ & - & - & - & $\begin{array}{l}\mathrm{R}^{2}=0.370 \\
\mathrm{p}=0.006 \\
N=19\end{array}$ & - & - & - & - & - \\
\hline Hair P & $\begin{array}{l}\mathrm{R}^{2}=0.981 \\
\mathrm{p}<0.001 \\
N=50\end{array}$ & $\begin{array}{l}\mathrm{R}^{2}<0.001 \\
\mathrm{p}=0.911 \\
N=49\end{array}$ & - & - & $\begin{array}{l}\mathrm{R}^{2}=0.990 \\
\mathrm{p}<0.001 \\
N=21\end{array}$ & $\begin{array}{l}\mathrm{R}^{2}=0.374 \\
\mathrm{p}=0.005 \\
N=19\end{array}$ & - & - & - & - \\
\hline Serum $P$ & $\begin{array}{l}\mathrm{R}^{2}<0.001 \\
\mathrm{p}=0.987 \\
N=48\end{array}$ & $\begin{array}{l}\mathrm{R}^{2}=0.018 \\
\mathrm{p}=0.347 \\
N=50\end{array}$ & $\begin{array}{l}\mathrm{R}^{2}<0.001 \\
\mathrm{p}=0.9334 \\
N=48\end{array}$ & - & $\begin{array}{l}\mathrm{R}^{2}=0.079 \\
\mathrm{p}=0.242 \\
N=19\end{array}$ & $\begin{array}{l}\mathrm{R}^{2}<0.001 \\
\mathrm{p}=0.947 \\
N=19\end{array}$ & $\begin{array}{l}\mathrm{R}^{2}=0.071 \\
\mathrm{p}=0.271 \\
N=19\end{array}$ & - & - & - \\
\hline Hair C & $\begin{array}{l}\mathrm{R}^{2}=0.229 \\
\mathrm{p}=0.001 \\
N=49\end{array}$ & $\begin{array}{l}\mathrm{R}^{2}=0.002 \\
\mathrm{p}=0.779 \\
N=48\end{array}$ & $\begin{array}{l}\mathbf{R}^{2}=0.201 \\
\mathrm{p}=0.001 \\
N=49\end{array}$ & $\begin{array}{l}\mathrm{R}^{2}=0.001 \\
\mathrm{p}=0.801 \\
N=48\end{array}$ & $\begin{array}{l}\mathrm{R}^{2}=0.132 \\
\mathrm{p}=0.105 \\
N=21\end{array}$ & $\begin{array}{l}\mathrm{R}^{2}=0.012 \\
\mathrm{p}=0.661 \\
N=19\end{array}$ & $\begin{array}{l}\mathrm{R}^{2}=0.097 \\
\mathrm{p}=0.170 \\
N=21\end{array}$ & $\begin{array}{l}\mathrm{R}^{2}<0.001 \\
\mathrm{p}=0.982 \\
N=19\end{array}$ & $\begin{array}{l}\mathrm{R}^{2}=0.050 \\
\mathrm{p}=0.117 \\
N=50\end{array}$ & $\begin{array}{l}\mathrm{R}^{2}=0.042 \\
\mathrm{p}=0.207 \\
N=40\end{array}$ \\
\hline Hair $\mathrm{T}$ & - & - & - & - & - & - & - & - & - & $\begin{array}{l}\mathrm{R}^{2}=0.041 \\
\mathrm{p}=0.215 \\
N=39\end{array}$ \\
\hline Age & $\begin{array}{l}\mathrm{R}^{2}=0.049 \\
\mathrm{p}=0.487 \\
N=12\end{array}$ & $\begin{array}{l}\mathrm{R}^{2}=0.039 \\
\mathrm{p}=0.536 \\
N=12\end{array}$ & $\begin{array}{l}\mathrm{R}^{2}=0.047 \\
\mathrm{p}=0.499 \\
N=12\end{array}$ & $\begin{array}{l}\mathrm{R}^{2}=0.008 \\
\mathrm{p}=0.777 \\
N=12\end{array}$ & $\begin{array}{l}\mathrm{R}^{2}=0.059 \\
\mathrm{p}=0.530 \\
N=9\end{array}$ & $\begin{array}{l}\mathrm{R}^{2}=0.029 \\
\mathrm{p}=0.686 \\
N=8\end{array}$ & $\begin{array}{l}\mathrm{R}^{2}=0.032 \\
\mathrm{p}=0.469 \\
N=9\end{array}$ & $\begin{array}{l}\mathrm{R}^{2}=0.192 \\
\mathrm{p}=0.276 \\
N=8\end{array}$ & $\begin{array}{l}\mathrm{R}^{2}=0.382 \\
\mathrm{p}=0.004 \\
N=20\end{array}$ & $\begin{array}{l}\mathrm{R}^{2}=0.520 \\
\mathrm{p}=0.008 \\
N=12\end{array}$ \\
\hline BMI & $\begin{array}{l}\mathrm{R}^{2}=0.025 \\
\mathrm{p}=0.284\end{array}$ & $\begin{array}{l}\mathrm{R}^{2}=0.042 \\
\mathrm{p}=0.166\end{array}$ & $\begin{array}{l}\mathrm{R}^{2}=0.024 \\
\mathrm{p}=0.294\end{array}$ & $\begin{array}{l}\mathrm{R}^{2}=0.046 \\
\mathrm{p}=0.191\end{array}$ & $\begin{array}{l}\mathrm{R}^{2}=0.219 \\
\mathrm{p}=0.050\end{array}$ & $\begin{array}{l}\mathrm{R}^{2}=0.028 \\
\mathrm{p}=0.503\end{array}$ & $\begin{array}{l}\mathrm{R}^{2}=0.201 \\
\mathrm{p}=0.062\end{array}$ & $\begin{array}{l}\mathrm{R}^{2}=0.034 \\
\mathrm{p}=0.505\end{array}$ & $\begin{array}{l}\mathrm{R}^{2}=0.020 \\
\mathrm{p}=0.383\end{array}$ & $\begin{array}{l}R^{2}=0.558 \\
p<0.001\end{array}$ \\
\hline Date & $\begin{array}{l}N=47 \\
\mathrm{R}^{2}=0.002 \\
\mathrm{p}=0.731 \\
N=50\end{array}$ & $\begin{array}{l}N=47 \\
\mathrm{R}^{2}=0.022 \\
\mathrm{p}=0.298 \\
N=51\end{array}$ & $\begin{array}{l}N=47 \\
\mathrm{R}^{2}=0.005 \\
\mathrm{p}=0.639 \\
N=50\end{array}$ & $\begin{array}{l}N=39 \\
\mathrm{R}^{2}<0.001 \\
\mathrm{p}=0.914 \\
N=51\end{array}$ & $\begin{array}{l}N=18 \\
\mathrm{R}^{2}=0.066 \\
\mathrm{p}=0.276 \\
N=20\end{array}$ & $\begin{array}{l}N=18 \\
\mathrm{R}^{2}=0.072 \\
\mathrm{p}=0.265 \\
N=19\end{array}$ & $\begin{array}{l}N=18 \\
\mathrm{R}^{2}=0.055 \\
\mathrm{p}=0.318 \\
N=20\end{array}$ & $\begin{array}{l}N=15 \\
\mathrm{R}^{2}<0.001 \\
\mathrm{p}=0.953 \\
N=19\end{array}$ & $\begin{array}{l}N=41 \\
\mathrm{R}^{2}=0.070 \\
\mathrm{p}=0.063 \\
N=50\end{array}$ & $\begin{array}{l}N=34 \\
\mathrm{R}^{2}=0.089 \\
\mathrm{p}=0.049 \\
N=44\end{array}$ \\
\hline
\end{tabular}


(Davenport et al., 2006), humans (Sharpley et al., 2010), and is reviewed in Stenn and Paus, (2001). Recent evidence suggests the potential for localized production of glucocorticoids in the skin, meaning that hair follicles and skin would be capable of synthesis and secretion of cortisol (Ito et al., 2005; Slominski et al., 2012). Therefore, it is possible that hair cortisol is a product of more than just central glucocorticoid sources (Sharpley et al., 2010; Keckeis et al., 2012). Human skin is able to produce and metabolize reproductive hormones (Barakat et al., 2016; Ceruti et al., 2018; Slominski et al., 2012), but the sources of polar bear hair cortisol and reproductive steroids are currently unclear.

There are multiple factors that may explain or may be contributing to the relationship between hair cortisol and capture date in the current study. Females with COY tend to be captured later in the season, which may bias cortisol concentrations between early and late capture season. It is also possible this relationship may be related to potential alternative mechanisms for hormone uptake from circulation into the hair follicle, which have been previously described (Cattet et al., 2014; Macbeth et al., 2012). Alternatively, this relationship may be related to hair growth pattern and timing in this species, although based on prior knowledge this seems to be during a period where hair growth is quiescent.

In a study in grizzly bears, hair cortisol concentrations were influenced in the short term by capture stress despite hair being in the quiescent phase (Cattet et al., 2014). If there are progressive stressors that cause increasing cortisol concentrations throughout the spring, these findings support the idea that passive diffusion from the vasculature may not be the only mechanism by which cortisol is integrated into hair. Alternatively, cortisol may still be entering the hair during the quiescent phase (telogen). Geyfman et al. (2015) described a multitude of cellular processes occurring during telogen suggesting that it may not truly be a period of rest. This study focused on murine models and may not be representative of polar bear follicle dynamics since only small regions of the coat are in telogen at once in mice, in comparison to the majority of the coat being in telogen for a long period of time in seasonal coat growers such as polar bears.

\subsection{Hair and serum}

Because serum and hair reflect the physiologic changes corresponding to different parts of the year and reproductive cycle, we are unable to use hair samples as a proxy for measuring breeding season (serum) hormone concentrations. However, this may be an option for estradiol in subadult females. The lack of correlation between progesterone, testosterone, and estradiol concentrations among adults was likely due to seasonal variation in reproductive hormones and the sampling time-frame, but also may be attributed to small sample sizes for age groups. Due to the probable timing of hormone deposition in hair, samples collected during our time period (spring) are representative of the reproductive hormone concentrations present in the previous summer, fall, and winter, but not the previous or current spring (Davenport et al., 2006). This may also explain why we see a significant relationship between hair and serum estradiol in subadults. Polar bears typically become reproductively mature at 5 years of age (Ramsay and Stirling, 1988), and immature females have not been shown to have an increase in serum estradiol during the hair growth season (Palmer et al., 1988). If there is less variation throughout the year in immature females then we may see a significant relationship in subadults but not adults. Alternatively, a negative association could mean the results are not biologically meaningful.

\section{Conclusion}

This study built upon previous studies showing that hair samples can be used successfully to measure progesterone, estradiol, and testosterone in female and male polar bears. Doing so will help us better understand current population reproductive physiology in this species of conservation concern, and could allow us to monitor for changes in stress physiology and reproductive health over time. In adult females, measuring hair hormones may be more useful than serum for understanding the interaction between reproduction, stress, and fitness because hair gives us a picture of multi-season averages rather than the snapshot time-frame that serum samples provide. Although samples examined here came from captured animals, polar bear hair can be collected using less invasive methods that are less stressful to the animal than physical capture. Moving forward, hair hormone analysis can help inform us about the reproductive and stress status of this endangered species so we can more successfully monitor this species in the wild.

\section{Funding}

This work was supported by the U.S. Geological Survey Changing Arctic Ecosystems initiative through the Wildlife Program of the Ecosystem Mission Area and USGS funding (\#G14AC00368 and \#G17AC00401) awarded to SSF and EMG, Utah State University Seed Program to Advance Research Collaboration (SPARC) awarded to EMG, PAT, TCA and SSF, and the U.S. Fish and Wildlife Service Arctic National Wildlife Refuge provided in-kind support.

\section{Acknowledgements}

We thank AC Webb and AM Durso for help conducting the assays, and G Durner, K Simac, A Pagano, and T Donnelly for help sampling polar bears. We would like to thank B Kleuver and anonymous reviewers for their time and comments on this manuscript. Research was approved by the Animal Care and Use Committees of the U.S. Geological Survey, Alaska Science Center and under the Marine Mammal Protection Act and Endangered Species Act with the U.S. Fish and Wildlife Service permit number MA690038. Data used in the analyses are available at https:// doi.org/10.5066/F7F76BDV. This paper was reviewed and approved by USGS under their Fundamental Science Practices policy (http://www. usgs.gov/fsp). Any use of trade, product, or firm names is for descriptive purposes only and does not imply endorsement by the U.S. Government. The findings and conclusions in this publication have not been formally disseminated by the U.S. Department of Agriculture and should not be construed to represent any agency determination or policy.

\section{References}

Amstrup, S.C., Gardner, C., 1994. Polar bear maternity denning in the Beaufort Sea. J. Wildl. Manage. 58 (1), 1. https://doi.org/10.2307/3809542.

Amstrup, S.C., 2003. Polar Bear, Ursus maritimus. In: Feldhamer, G.A., Thompson, B.C., Chapman, J.A. (Eds.), Wild Mammals of North America: biology, management, and conservation. John Hopkins University Press, Baltimore, pp. 587-610.

Atkinson, S.N., Ramsay, M.A., 1995. The effects of prolonged fasting of the body composition and reproductive success of female polar bears (Ursus maritimus). Funct. Ecol. 9 (4), 559. https://doi.org/10.2307/2390145.

Atwood, T.C., Marcot, B.G., Douglas, D.C., Amstrup, S.C., Rode, K.D., Durner, G.M., Bromaghin, J.F., 2016. Forecasting the relative influence of environmental and anthropogenic stressors on polar bears. Ecosphere 7 (6), e01370.

Barakat, R., Oakley, O., Kim, H., Jin, J., Ko, C.J., 2016. Extra-gonadal sites of estrogen biosynthesis and function. BMB Rep. 49 (9), 488-496.

G.R. Bortolotti T.A. Marchant J. Blas T. German Corticosterone in feathers is a long-term, integrated measure of avian stress physiology 2232008494500.

Bechshøft, T.Ø., Sonne, C., Rigét, F.F., Letcher, R.J., Novak, M.A., Henchey, E., Meyer, J. S., Eulaers, I., Jaspers, V.L.B., Covaci, A., Dietz, R., 2013. Polar bear stress hormone cortisol fluctuates with the North Atlantic Oscillation climate index. Polar Biol. 36 (10), 1525-1529.

Bengtson, J.L., Hiruki-Raring, L.M., Simpkins, M.A., Boveng, P.L., 2005. Ringed and bearded seal densities in the eastern Chukchi Sea, 1999-2000. Polar Biol. 28 (11), 833-845.

Brenner, R.M., West, N.B., 1975. Hormonal Regulation of the Reproductive Tract in Female Mammals. Annu. Rev. Physiol. 37 (1), 273-302.

Bromaghin, J.F., McDonald, T.L., Stirling, I., Derocher, A.E., Richardson, E.S., Regehr, E. V., Douglas, D.C., Durner, G.M., Atwood, T., Amstrup, S.C., 2015. Polar bear population dynamics in the southern Beaufort Sea during a period of sea ice decline. Ecol. Appl. 25 (3), 634-651.

Brooks, K.C., Mateo, J.M., 2013. Chronically raised glucocorticoids reduce innate immune function in Belding's ground squirrels (Urocitellus beldingi) after an immune challenge. Gen. Comp. Endocrinol. 193, 149-157. 
Bryant, J.L., Roth, T.L., 2018. Annual faecal glucocorticoid metabolite concentrations in pregnant and pseudopregnant polar bears (Ursus maritimus) in North American zoos. J. Zoo. Aquar. Res. 6 (1).

Cattet, M.R.L., Caulkett, N.A., Obbard, M.E., Stenhouse, G.B., 2002. A body-condition index for ursids. Can. J. Zool. 80 (7), 1156-1161.

M. Cattet B.J. Macbeth D.M. Janz A. Zedrosser J.E. Swenson M. Dumond G.B. Stenhouse Quantifying long-term stress in brown bears with the hair cortisol concentration: a biomarker that may be confounded by rapid changes in response to capture and handling Conserv. Physiol. 212014 cou026 cou26.

Cattet, M., Stenhouse, G.B., Janz, D.M., Kapronczai, L., Anne Erlenbach, J., Jansen, H.T., Nelson, O.L., Robbins, C.T., Boulanger, J., 2017. The quantification of reproductive hormones in the hair of captive adult brown bears and their application as indicators of sex and reproductive state. Conserv. Physiol. 5 (1).

J.M. Ceruti G.J. Leirós M.E. Balañá Androgens and androgen receptor action in skin and hair follicles 4652018122133.

Ciesielski, T.M., Hansen, I.T., Bytingsvik, J., Hansen, M., Lie, E., Aars, J., Jenssen, B.M., Styrishave, B., 2017. Relationships between POPs, biometrics, and circulating steroids in male polar bears (Ursus maritimus) from Svalbard. Envrion. Pollut. 230, 598-608.

Cook, N.J., 2012. Review: Minimally invasive sampling media and the measurement of corticosteroids as biomarkers of stress in animals. Can. J. Anim. Sci. 92 (3), 227-259.

Curry, E., Roth, T.L., MacKinnon, K.M., Stoops, M.A., 2012. Factors influencing annual fecal testosterone metabolite profiles in captive male polar bears (Ursus maritimus). Reprod. Domest. Anim. 47, 222-225.

Davenport, M.D., Tiefenbacher, S., Lutz, C.K., Novak, M.A., Meyer, J.S., 2006. Analysis of endogenous cortisol concentrations in the hair of rhesus macaques. Gen. Comp. Endocrinol. 147 (3), 255-261.

Derocher, A.E., Stirling, I., Andriashek, D., 1992. Pregnancy rates and serum progesterone levels of polar bears in western Hudson Bay. Can. J. Zool. 70 (3), 561-566.

Derocher, A.E., Lynch, W., 2012. Polar Bears: A complete guide to their biology and behavior. Johns Hopkins University Press, Baltimore, Maryland.

Dhabhar, F.S., 2009. Enhancing versus suppressive effects of stress on immune function: implications for immunoprotection and immunopathology. NeuroImmunoModulation 16 (5), 300-317.

Durner, G.M., Douglas, D.C., Nielson, R.M., Amstrup, S.C., McDonald, T.L., Stirling, I., Mauritzen, M., Born, E.W., Wiig, Ø., DeWeaver, E., Serreze, M.C., Belikov, S.E., Holland, M.M., Maslanik, J., Aars, J., Bailey, D.A., Derocher, A.E., 2009. Predicting 21st-century polar bear habitat distribution from global climate models. Ecol. Monogr. 79 (1), 25-58.

Durner, G.M., Douglas, D.C., Atwood, T.C., 2019. Are polar bear habitat resource selection functions developed from 1985-1995 data still useful? Ecol. Evol. 9 (15), 8625-8638.

Edgren, R.A., Jones, R.C., Peterson, D.L., 1967. A biological classification of progestational agents. Fertil. Steril. 18 (2), 238-256.

Geyfman, M., Plikus, M.V., Treffeisen, E., Andersen, B., Paus, R., 2015. Resting no more: re-defining telogen, the maintenance stage of the hair growth cycle. Biol. Rev. 90 (4), 1179-1196.

Greff, M.J.E., Levine, J.M., Abuzgaia, A.M., Elzagallaai, A.A., Rieder, M.J., van Uum, S.H. M., 2019. Hair cortisol analysis: an update on methological considerations and clinical applications. Clin. Biochem. 63, 1-9.

Gustavson, L., Jenssen, B.M., Bytingsvik, J., Styrishave, B., Hansen, M., Aars, J., Eggen, G.S., Ciesielski, T.M., 2015. Steroid hormone profile in female polar bears (Ursus maritimus). Biolar Biol 38 (8), 1183-1194.

Harwood, L.A., Smith, T.G., Auld, J.C., 2012. Fall migration of ringed seals (Phoca hispida) through the Beaufort and Chukchi Seas, 2001-02. Arctic 35-44.

Haave, M., Ropstad, E., Derocher, A.E., Lie, E., Dahl, E., Wiig, Ø., Skaare, J.U., Jenssen, B.M., 2003. Polychlorinated biphenyls and reproductive hormones in female polar bears at Svalbard. Environ. Health Perspect. 111 (4), 431-436.

Heimbürge, S., Kanitz, E., Otten, W., 2019. The use of hair cortisol for the assessment of stress in animals. Gen. Comp. Endocr. 270, 10-17.

Herreman, J., Peacock, E., 2013. Polar bear use of a persistent food subsidy: insights from non-invasive genetic sampling in Alaska. Ursus 24 (2), 148-163.

Howell-Skalla, L., 2002. Seasonal changes in testicular size and serum LH, prolactin and testosterone concentrations in male polar bears (Ursus maritimus). Reproduction 123 (5), 729-733.

Ito, N., Ito, T., Kromminga, A., Bettermann, A., Takigawa, M., Kees, F., Straub, R.H., Paus, R., 2005. Human hair follicles display a functional equivalent of the hypothalamic-pituitary-adrenal axis and synthesize cortisol. FASEB J 19 (10), 1332-1334.

Keckeis, K., Lepschy, M., Schöpper, H., Moser, L., Troxler, J., Palme, R., 2012. Hair cortisol: a parameter of chronic stress? Insights from a radiometabolism study in guinea pigs. J. Comp. Physiol., B 182 (7), 985-996.

Knott, K.K., Mastromonaco, G.F., Owen, M.A., Kouba, A.J., 2017. Urinary profiles of progestin and androgen metabolites in female polar bears during parturient and nonparturient cycles. Conserv. Physiol. 5 (1).

Kroshko, T., Kapronczai, L., Cattet, M.R.L., Macbeth, B.J., Stenhouse, G.B., Obbard, M.E., Janz, D.M., 2017. Comparison of methanol and isopropanol as wash solvents for determination of hair cortisol concentration in grizzly bears and polar bears. MethodsX 4, 68-75.

Lillie, K.M., Gese, E.M., Atwood, T.C., Conner, M.M., 2019. Use of subsistence-harvested whale carcasses by polar bears in the southern Beaufort Sea. Arctic 72 (4), 404-412.

Macbeth, B.J., Cattet, M.R.L., Stenhouse, G.B., Gibeau, M.L., Janz, D.M., 2010. Hair cortisol concentration as a noninvasive measure of long-term stress in free-ranging grizzly bears (Ursus arctos): considerations with implications for other wildlife. Can. J. Zool. 88 (10), 935-949.
Macbeth, B.J., Cattet, M.R.L., Obbard, M.E., Middel, K., Janz, D.M., 2012. Evaluation of hair cortisol concentration as a biomarker of long-term stress in free-ranging polar bears. Wildl. Soc. Bull. 36 (4), 747-758.

Mislan, P., Derocher, A.E., St. Louis, V.L., Richardson, E., Lunn, N.J., Janz, D.M., 2016. Assessing stress in Western Hudson Bay polar bears using hair cortisol concentration as a biomarker. Ecol. Indic. 71, 47-54.

Molnár, P.K., Derocher, A.E., Klanjscek, T., Lewis, M.A., 2011. Predicting climate change impacts on polar bear litter size. Nat Commun 2, 186.

Molnár, P.K., Bitz, C.M., Holland, M.M., Kay, J.E., Penk, S.R., Amstrup, S.C., 2020. Fasting season length sets temporal limits for global polar bear persistence. Nat. Clim. Change 10 (8), 732-738.

Moore, M.C., 1986. Elevated testosterone levels during nonbreeding-season territoriality in a fall-breeding lizard, Sceloporus jarrovi. J. Comp. Physiol., A 158 (2), 159-163.

Neuman-Lee, L.A., Bobby Fokidis, H., Spence, A.R., Van der Walt, M., Smith, G.D., Durham, S., French, S.S., Tschirren, B., 2015. Food restriction and chronic stress alter energy use and affect immunity in an infrequent feeder. Funct. Ecol. 29 (11), 1453-1462.

Neuman- Lee, L.A., Terletzky, P.A., Atwood, T.C., Gese, E.M., Smith, G.D., Greenfield, S., Pettit, J., French, S.S., 2017. Demographic and temporal variations in immunity and condition of polar bears (Ursus maritimus) from the southern Beaufort Sea. J. Exp. Zool. Part A 327 (5), 333-346.

Obbard, M.E., Cattet, M.R.L., Howe, E.J., Middel, K.R., Newton, E.J., Kolenosky, G.B., Abraham, K.F., Greenwood, C.J., 2016. Trends in body condition in polar bears (Ursus maritimus) from the Southern Hudson Bay subpopulation in relation to changes in sea ice. Arct. Sci. 2 (1), 15-32.

Oskam, I.C., Ropstad, E., Dahl, E., Lie, E., Derocher, A.E., Wiig, ๑., Larsen, S., Wiger, R., Skaare, J.U., 2003. Organochlorines affect the major androgenic hormone, testosterone, in male polar bears (Ursus maritimus) at Svalbard. J. Toxicol. Environ. Health Part A 66 (22), 2119-2139.

Pagano, A.M., Durner, G.M., Rode, K.D., Atwood, T.C., Atkinson, S.N., Peacock, E., Costa, D.P., Owen, M.A., Williams, T.M., 2018. High-energy, high-fat lifestyle challenges an Arctic apex predator, the polar bear. Science 359 (6375), 568-572.

Palmer, S., Nelson, R., Ramsay, M., Stirling, I., Bahr, J., 1988. Annual changes in serum sex steroids in male and female black (Ursus americanus) and polar (Ursus maritimus) bears. Biol. Reprod. 38 (5), 1044-1050.

Ramsay, M.A., Stirling, I., 1988. Reproductive biology and ecology of female polar bears (Ursus maritimus). J. Zool. 214 (4), 601-633.

Regehr, E.V., Hunter, C.M., Caswell, H., Amstrup, S.C., Stirling, I., 2010. Survival and breeding of polar bears in the southern Beaufort Sea in relation to sea ice. J. Anim. Ecol. 79 (1), 117-127.

Robbins, C.T., Ben-David, M., Fortin, J.K., Nelson, O.L., 2012. Maternal condition determines birth date and growth of newborn bear cubs. J. Mammal. 93 (2), 540-546.

Rode, K.D., Amstrup, S.C., Regehr, E.V., 2010. Reduced body size and cub recruitment in polar bears associated with sea ice decline. Ecol. Appl. 20 (3), 768-782.

Rode, K.D., Olson, J., Eggett, D., Doughlas, D.C., Durner, G.M., Atwood, T.C., Regehr, E. V., Wilson, R.R., Smith, T., St. Martin, M., 2018. Den phenology and reproductive success of polar bears in a changing climate. J. Mammal. 99 (1), 16-26.

Russell, E., Koren, G., Rieder, M., Van Uum, S., 2012. Hair cortisol as a biological marker of chronic stress: current status, future directions and unanswered questions. Psychoneuroendocrinology 37 (5), 589-601.

Serreze, M.C., Barry, R.G., 2011. Processes and impacts of Arctic amplification: A research synthesis. Global Planet Change 77 (1-2), 85-96.

Sharpley, C.F., Kauter, K.G., McFarlane, J.R., 2010. An Investigation of Hair Cortisol Concentration Across Body Sites and within Hair Shaft. Clin. Med. Insights Endocrinol Diabetes 3, 17-23.

Sheriff, M.J., Dantzer, B., Delehanty, B., Palme, R., Boonstra, R., 2011. Measuring stress in wildlife: Techniques for quantifying glucocorticoids. Oecologia 166, 869-887.

Slominski, A.T., Zmijewski, M.A., Skobowiat, C., Zbytek, B., Slominski, R.M., Steketee, J. D., 2012. Sensing the environment: Regulation of local and global homeostasis by the skin neuroendocrine system. Adv. Anat. Embryol. Cell Biol. 212 (115).

Smith, T.G., Aars, J., 2015. Polar bears (Ursus maritimus) mating during late June on the pack ice of northern Svalbard. Norway. Pol. Res. 34 (1), 25786. https://doi.org/ 10.3402/polar.v34.25786.

Stenn, K.S., Paus, R., 2001. Controls of hair follicle cycling. Physiol. Rev. 81 (1), 449-494.

Stern, H.L., Laidre, K.L., 2016. Sea-ice indicators of polar bear habitat. Cryosphere 10 (5), 2027-2041.

Stirling, I., Spencer, C., Andriashek, D., 2016. Behavior and activity budgets of wild breeding polar bears (Ursus maritimus). Mar. Mamm. Sci. 32 (1), 13-37.

Stoops, M.A., MacKinnon, K.M., Roth, T.L., 2012. Longitudinal fecal hormone analysis for monitoring reproductive activity in the female polar bear (Ursus maritimus). Theriogenology 78 (9), 1977-1986.

Stroeve, J.C., Markus, T., Boisvert, L., Miller, J., Barrett, A., 2014. Changes in Arctic melt season and implications for sea ice loss. Geophys. Res. Lett. 41 (4), 1216-1225.

Thiemann, G.W., Iverson, S.J., Stirling, I., 2006. Seasonal, sexual and anatomical variability in the adipose tissue of polar bears (Ursus maritimus). J. Zool. 269 (1), 65-76.

Tilbrook, A.J., Turner, A.I., Clarke, I.J., 2000. Effects of stress on reproduction in nonrodent mammals: the role of glucocorticoids and sex differences. Rev. Reprod. 5, $105-113$.

Wingfield, J.C., Maney, D.L., Breuner, C.W., Jacobs, J.D., Lynn, S., Ramenofsky, M., Richardson, R.D., 1998. Ecological Bases of Hormone-Behavior Interactions: The "Emergency Life History Stage". Am. Zool. 38, 191-206.

Wingfield, J.C., Sapolsky, R., 2003. Reproduction and Resistance to Stress: When and How. Neuroendocrinology 15, 711-724. 